\title{
TEROBOSAN KREATIF KEPOLISIAN PERAIRAN POLDA BANTEN DALAM PELAKSANAAN PEMELIHARAAN KEAMANAN MASYARAKAT DAN PENEGAKAN HUKUM DI PERAIRAN SELAT SUNDA
}

\section{Creative Breakthrough Marine Police Banten in the Implementation of Maintenance Security Public and Law Enforcement in the Strait Sunda}

\author{
Danial \\ Fakultas Hukum Universitas Sultan Ageng Tirtayasa, \\ email: bontobangun@gmail.com
}

\begin{abstract}
Marine Police Regional Police Banten Province is breakthrough in the development of creative, aware of the importance of knowledge of the social and cultural life of the operational environment. However, the problem is: First, how the pattern of development of the concept of Creative Breakthroughs Marine Police Banten ?; Second, how the implementation of the concept of creative breakthrough Marine Police Banten?. The results showed that the First, Pattern Creative Breakthrough Development undertaken in the framework of Banten Water Police Pushing Water existence in Banten Police are doing synchronization and coordination with the Department of Maritime Province of Banten in terms of the measurement vessel, Formulation of Local Regulations related to service to the fishermen and the plan of Units waters; Secondly, optimization of local government support, Academics to Overcome situation, needs and implementing creative breakthroughs Marine Police Banten in order to protect, Protects, Serving Society, and Law Enforcement The Regional Water can be embodied through preemptive action, preventive and educative as well as ongoing collaboration with the form as a container maritime forum gathering agencies in charge of maritime waters and ports in Province of Banten.
\end{abstract}

Keywords: Creative Breakthroughs, Marine Police, Security, Law Enforcement, Sunda Strait

\begin{abstract}
abstrak
Kepolisian Perairan Banten dalam upaya pengembangan terobosan kreatifnya, sadar akan pentingnya pengetahuan terhadap kehidupan sosial dan budaya lingkungan operasionalnya. Namun, masalahnya adalah: Pertama, bagaimana Pola Pengembangan konsep Terobosan Kreatif Kepolisian Perairan (sebagaimana disingkat menjadi Polair) Polda Banten?;
\end{abstract}


Kedua, bagaimana konsep pengimplementasian terobosan kreatif Kepolisian Perairan Polda Banten?. Hasil penelitian menunjukkan bahwa: Pertama, Pola Pengembangan Terobosan Kreatif yang di lakukan Kepolisian Perairan Banten dalam Rangka Mendorong Eksistensi Kepolisian Perairan di Banten adalah melakukan sinkronisasi dan koordinasi dengan Dinas Maritim Provinsi Banten dalam hal pengukuran Kapal, Perumusan Peraturan Daerah terkait dengan pelayanan terhadap nelayan dan rencana pembuatan samsat perairan; Kedua, Optimalisasi dukungan Pemda, Akademisi Guna Mengatasi Situasi, Kebutuhan dan pengimplementasian terobosan kreatif Kepolisian Perairan Banten dalam rangka Melindungi, Mengayomi, Melayani Masyarakat, Serta Penegakkan Hukum di Wilayah Perairan dapat di wujudkan melalui tindakan Preemtif, Preventif dan Edukatif serta kerjasama yang berkelanjutan dengan membentuk forum maritim sebagai wadah berkumpulnya instansi-instansi yang membidangi wilayah perairan maritim serta pelabuhan-pelabuhan di Provinsi Banten.

Kata Kunci: Terobosan Kreatif, Kepolisian Perairan, Keamanan, Penegakan Hukum, Selat Sunda

\section{A. Pendahuluan}

Perairan Banten merupakan salah satu daerah perlintasan pelayaran yang sangat strategis di Indonesia yang di kenal dengan istilah alur laut kepulauan Indonesia satu (ALKI 1) yang posisinya berada di selat sunda. Wilayah Banten terletak di antara $5^{\circ} 7^{\prime} 50^{\prime \prime}-7^{\circ} 11^{\prime} 11^{\prime \prime}$ Lintang Selatan dan $105^{\circ} 1^{\prime} 11^{\prime \prime}-106^{\circ} 7^{\prime} 12^{\prime \prime}$ Bujur Timur, berdasarkan Undang-Undang Republik Indonesia Nomor 23 tahun 2000 luas wilayah Banten adalah 9.160,70 km². Provinsi Banten terdiri dari 4 kota, 4 kabupaten, 154 kecamatan, 262 kelurahan, dan 1.273 desa. Wilayah laut Banten merupakan salah satu jalur laut potensial, Selat Sunda merupakan salah satu jalur lalu lintas laut yang strategis karena dapat dilalui kapal besar yang menghubungkan Australia dan Selandia Baru dengan kawasan Asia Tenggara misalnya Thailand, Malaysia, dan Singapura.

Wilayah perairan Banten khususnya dan Indonesia pada umumnya memiliki potensi kekayaan minyak dan gas bumi yang terdapat di dasar laut dan tanah dibawahnya yang melimpah. Namun, perairan Banten juga rawan dijadikan aksi penyelundupan, diantaranya narkoba, daging babi dan binatang langka, aksi tindak pidana penyelundupan, seperti illegal fishing atau penyelundupan ikan, illegal oil atau penyelundupan Bahan Bakar Minyak (BBM) dan human traficking atau para pencari suaka serta People smuggling. People smuggling dikategorikan sebuah kejahatan karena people smuggling merupakan suatu tindakan melanggar hak asasi manusia dan bentuk perbudakan kontemporer. Para imigran diperlakukan dengan tidak 
baik. Sangat sering kondisi perjalanan yang tidak manusiawi, ditumpuk dalam angkutan (umumnya perahu) yang penuh dan sesak, dan bahkan sering terjadi kecelakaan yang fatal. Setibanya di tempat tujuan, status ilegal mereka menyebabkan mereka terpaksa menjadi budak para penyelundup yang memaksa bekerja selama bertahun-tahun di pasar tenaga kerja ilegal. Para imigran secara tidak langsung dieksploitasi oleh pihak tertentu demi keuntungan materil. ${ }^{1}$

Kejahatan People smuggling sering melintasi selat sunda menjadi lahan bisnis tersendiri yang sangat menguntungkan. Diperkirakan setiap tahunnya dapat menghasilkan keuntungan sebesar lima hingga sepuluh juta dolar. Berdasarkan perkiraan tersebut, setidaknya satu juta imigran harus membayar rata-rata sebesar lima hingga sepuluh ribu dolar secara paksa ketika melintasi perbatasan antar negara. Organisasi Internasional untuk Migrasi (IOM) mencatat bahwa penyelundupan manusia, yang merupakan "sisi gelap" dari globalisasi, adalah sebuah bisnis besar yang kian tumbuh dan berkembang. Selain itu, people smuggling juga menimbulkan masalah tersendiri bagi negara tempat mereka meminta suaka. ${ }^{2}$

Oleh karena itu, pemeliharaan keamanan dan ketertiban serta penegakan hukum di perairan selat sunda menjadi tugas utama Kepolisian Perairan Polda Banten. Terkait dengan kewenangan keamanan Negara oleh kepolisian dalam melindungi, mengayomi, melayani masyarakat, serta menegakkan hukum yang diatur dalam Pasal 2 Undang-Undang nomor 2 tahun 2002 tentang kepolisian. Maka dalam rangka peningkatan kualitas pelayanan sesuai dengan Reformasi Birokrasi Polri, Dit Polair Polda Banten telah melakukan terobosan kreatif berupa kegiatan sinkronisasi pelayanan terhadap kapal nelayan di wilayah hukum polda Banten. Hal ini dilakukan berdasarkan analisa dan evaluasi penanganan berbagai gangguan keamanan laut seperti pelanggaran kedaulatan, pelanggaran wilayah, perompakan, illegal fishing, illegal logging, penyelundupan, kecelakaan laut, pencurian harta karun dan lain-lain ${ }^{3}$. Khusus Illegal Fishing di wilayah perairan Banten selama tahun 2010 sampai dengan 2014 yang sangat di pengaruhi oleh:

1. Di wilayah Banten terdapat Alur Laut Kepulauan Indonesia (ALKI 1);

2. Budaya hukum masyarakat pesisir masih rendah;

3. Minimnya pengetahuan dan pemahaman birokrasi Pemerintah Daerah tentang kewenangan dalam pelaksanaan pelayanan terhadap nelayan sebagai akibat dari lemahnya produk hukum daerah yang menyangkut perizinan usaha perikanan yang di keluarkan oleh dinas terkait.

\footnotetext{
${ }^{1}$ http://www.polair.polri.go.id/index.php?option=com_content\&view=article\&id=1061\&Itemi $\mathrm{d}=597$ di akses tanggal 1 Oktober 2014

2 http://female.kompas.com, diakses pada tanggal 23 November 2009.

${ }^{3}$ http://www.pelita.or.id/baca.php?id=97609 di akses tanggal 12 Juli 2014
} 
Situasi tersebut di atas sangat di pengaruhi rendahnya tingkat pendidikan masyarakat pesisir, kurangnya sosialisasi hukum, ego sektoral antar instansi terkait serta keterbatasan sarana dan prasarana yang dimiliki oleh aparat penegak hukum khususnya di lingkungan Kepolisian Perairan Polda Banten. Oleh karena itu, dalam upaya peningkatan pelayanan tersebut Dit Polair Polda Banten menyelenggarakan terobosan kreatif pelayanan penegakan hukum dengan program penertiban dokumen kapal nelayan dan perizinan usaha perikanan di wilayah hukum Polda Banten dengan kegiatan sinkronisasi dengan instansi pemerintah yang terkait dalam pelayanan terhadap nelayan sehingga tidak ditemukan adanya penyalahgunaan wewenang dan meningkatkan pelayanan kepada nelayan sehingga ke depan kemitraan antara nelayan dan instasi terkait dapat terjalin yang bersamasama menjaga keamanan dan ketertibatan masyarakat nelayan dapat tercipta. Namun, masalahnya adalah bagaimana Pola Pengembangan konsep Terobosan Kreatif Polair Polda Banten?; dan bagaimana konsep pengimplementasian terobosan kreatif Polair Polda Banten?

\section{B. Pembahasan}

\section{Pola Pengembangan konsep Terobosan Kreatif Polair Polda Banten}

Polair Polda Banten dalam upaya pengembangan terobosan kreatifnya, sadar tentang pentingnya pengetahuan lebih luas mengenai kehidupan sosial dan budaya lingkungan operasionalnya. Oleh karena itu, Polair Polda Banten mengedepankan dan memiliki sikap keterbukaan dalam menjalankan operasional dan tugasnya sebagai abdi masyarakat dan sebagai pengayom masyarakat serta mengimplementasikan konsep Preemtif, Preventif dan edukatif dalam mencapai tujuannya. Secara pewilayahan daerah operasional Mako Dit Pol Air Polda Banten berkedudukan di sebelah Utara Merak dengan letak Geografis $106^{0} 00^{\prime} 00^{\prime \prime}$ LS dan $05^{\circ} 95^{\prime} 00^{\prime \prime}$ BT dan memunyai wilayah Hukum mulai dari Tirtayasa Kabupaten Serang sampai dengan Malingping Kabupaten Lebak termasuk sungai-sungai yang dapat dilayari sejauh 256,9 Mil, serta Pos Pol Air jajaran Dit Pol Air Polda Banten dapat dipetakan berdasarkan kawasan. Selain itu, Wilayah Hukum Direktorat Kepolisian Perairan Polda Banten merupakan gerbang jalur lalu lintas penyeberangan antara Jawa-Sumatera dan sebaliknya, sehingga memiliki kaitan yang sangat erat dengan Daerah Ibu Kota Jakarta aspek Tri Gatra maupun Panca Gatra dan berbatasan dengan Propinsi Lampung serta Alur laut kepulauan Indonesia merupakan lalu lintas kapal-kapal menuju Australia maupun sebaliknya, sehingga rawan terhadap berbagai gangguan kamtibmas. Daerah-daerah yang di kategorikan rawan yaitu: Kawasan 
Karangantu, Kawasan Bojonegara, Kawasan Anyar, Kawasan Panimbang, Kawasan Binuangeun, Kawasan Pulau Tunda, dan Kawasan Sumur. ${ }^{4}$

Jadi, Secara umum dan berdasarkan trend gangguan KAMTIBMAS di wilayah hukum Direktorat Kepolisian Perairan Polda Banten pada tahun 2014 bila dibandingkan dengan tahun 2012 dan 2013 dari segi kuantitas mengalami penurunan jumlah kejadian dengan adanya upaya peningkatan aktivitas di wilayah hukum Direktorat Kepolisian Perairan Polda Banten dalam hal penindakan, pemberdayaan patroli perairan, Polmas perairan dan Sambang Nusa akan lebih efektif di dalam menekan tindak pidana untuk menciptakan dan memelihara Keamanan dan Ketertiban masyarakat perairan. $^{5}$

Oleh karena itu, dalam menjalankan tugas operasionalnya secara struktural diharapkan dukungan legalitas dan kerangka politik dalam mengawal tugas Polair. Pentingnya penguatan pengawalan lingkungan sistem pemerintahan dan politik, agar Polair dapat bergerak di lapangan sesuai dengan fungsi dan kewenangannya. Pentingnya untuk memahami sistem pemerintah dan politik suatu era untuk memahami dan menjelaskan perilaku, kinerja, dan organisasi Polair itu sendiri. Dalam sistem politik yang mengenal pemisahan kekuasaan antara legislatif, eksekutif dan yudikatif, maka polisi adalah bagian dari eksekutif yang menjalankan fungsinya berdasarkan strukturnya. ${ }^{6}$

Untuk mencapai pemenuhan kebutuhan sistem maka diperlukan suatu tindakan fungsionalisme struktural bahwa fungsi dijabarkan dalam empat sistem yaitu pertama, adaptation (adaptasi): sebuah sistem harus menanggulangi situasi eksternal yang gawat dan sistem harus menyesuaikan diri dengan lingkungan dan menyesuaikan lingkungan itu dengan kebutuhannya; Kedua, goal attainment (pencapaian tujuan): sebuah sistem harus mendefinisikan dan mencapai tujuan utamanya; Ketiga, integration (integrasi): sebuah sistem harus mengatur dan mengelola antarhubungan bagian-bagian yang menjadi komponenya; Keempat, latency (latensi atau pemeliharaan pola) adalah sebuah sistem harus dilengkapi pemeliharaan dan memperbaiki, baik motivasi individual maupun pola-pola kultural yang menciptakan dan menopang motivasi. ${ }^{7}$

Dalam rangka peningkatan kualitas pelayanan sesuai dengan Reformasi Birokrasi Polri, Dit Polair Polda Banten melakukan terobosan

\footnotetext{
${ }^{4}$ Data ini di peroleh dari Subdit Gakum Polair Polda Banten

${ }^{5}$ M. Khoidin Sadjijono, Menatap Wajah Polisi Kita, (Yogyakarta: Laksbang PRESSindo, 2005), hlm. 3.

${ }^{6}$ Roy R Roberg, Police Management, Terjemahan oleh PTIK, (Jakarta: PTIK, 2013), hlm. 15.

7 Sirajuddin, dkk, Komisi Pengawas Penegak Hukum, (Malang: Malang Corruption Watch dan Yappika, 2007), hlm. 20.
} 
kreatif. Adapun terobosan kreatif yang dilakukan oleh Polair Polda Banten adalah sebagai berikut:

\section{a. Sinkronisasi Program Kerja dengan Instansi Maritim terhadap Pelayanan Kapal Nelayan}

Sinkronisasi merupakan suatu hal yang penting dilakukan sebagai bentuk penguatan lembaga dan dapat diposisikan sebagai lini terdepan dalam penegakan hukum di wilayah polda Banten. Untuk mewujudkan terobosan kreatif tersebut bukanlah hal yang mudah bagi jajaran Polair dan khususnya Subdit Gakkum Polair Polda Banten. Terobosan ini dilakukan sebenarnya diawali dari evaluasi penanganan kasus illeggal fishing sejak tahun 2010 hingga tahun 2011. Sistem tindakan yang dilakukan oleh Polair Polda Banten sudah bagian dari pelaksanaan fungsi adaptasi sebagaimana yang di kemukakan oleh Parsons. Parsons mengatakan bahwa fungsi adaptasi adalah proses penyesuaikan diri dengan lingkungannya. Polair sebagai subsistem kepribadian harus mampu melaksanakan fungsi pencapaian tujuan dengan menetapkan tujuan sistem dan memobilisasi sumber daya yang ada untuk mencapainya. ${ }^{8}$

Melalui sistem kepribadian itu, Polair harus mampu melakukan terobosan sinkronisasi karena kondisi di lapangan masih banyak ditemukan masyarakat nelayan yang tidak taat dan patuh terhadap Undang-undang dan peraturan tentang batasan perizinan penggunaan perahu dan alat tangkap yang digunakan. Deteksi awal ini disebabkan pula minimnya pengetahuan dan pemahaman instansi yang terkait dalam membagi kewenangan dalam pelaksanaan pelayanan terhadap nelayan. Selain itu ketegasan dari birokrasi dalam mengeluarkan peraturan hukum mengakibatkan izin untuk berlayar sangat sulit untuk diperoleh. Akibat dari sulitnya itu, karena terlalu banyak lembaga yang terlibat dalam penanganan kapal nelayan, sehingga birokrasi terlalu panjang. Untuk pelayanan itu sebenarnya sudah dapat tersentralisasi di Polair saja, dan selanjutnya Polair melakukan koordinasi dengan instansi lainnya. Dengan pola pengembangan terobosan kreatif Polair Polda Banten, dapat teridentifikasi permasalahan-permasalahan nelayan.

Berdasarkan analisa dan evaluasi penanganan kasus Ileggal Fishing pada Wilayah Hukum Direktorat Kepolisian Perairan Polda Banten selama tahun 2010 sampai dengan 2014 ditemukan adanya dokumen kapal dan perizinan usaha perikanan yang temukan tidak sesuai dengan kondisi fisik kapal dengan yang ada di dokumen dan prosedur penerbitan dokumen yang tidak didasarkan pada undang-undang dan peraturan yang berlaku hal ini dapat menimbulkan permasalahan hukum baik pada nelayan maupun dinas instansi yang menerbitkan dokumen kapal nelayan, Dari data Jumlah kapal

\footnotetext{
${ }^{8}$ Taswin, Kumpulan hasil laporan Polair Polda Banten sejak tahun 2000 - 2014.
} 
nelayan yang ada di hukum Polda Banten terdapat kurang lebih 5.000 kapal nelayan.

Pengumpulan data nelayan di seluruh wilayah hukum yang menjadi kewenangan Wilayah Hukum Direktorat Kepolisian Perairan Polda Banten yang meliputi Pas Kecil Kapal, SIUP, SIPI serta Surat keterangan Kecakapan Nelayan. Pengumpulan data itu, dilakukan untuk memperoleh informasi dan pendapat nelayan dalam pelayanan birokrasi terhadap terbitnya surat-surat kapal dan perizinan usaha perikanan. ${ }^{9}$

Melakukan pengukuran ulang terhadap 5 (lima) buah kapal yang ditangani dengan pelangggaran berlayar tanpa Surat Persetujuan Berlayar, di mana hasil pengukuran ditemukan Gross Tonase (GT) kapal tidak sesuai dengan dokumen kapal yang dimiliki oleh pemilik kapal. Proses hukum yang dialami oleh nelayan pada Wilayah Hukum Direktorat Kepolisian Perairan Polda Banten antara lain sebagai berikut:

1) permasalahan nelayan terkait proses penerbitan surat kapal seperti Pas Kecil, Pas Tahunan serta sertifikat Keselamatan kapal yang dilakukan oleh instansi yang berwenang menerbitkan dokumen- dokumen tersebut;

2) permasalahan nelayan dalam pelayanan SIUP dan SIPI;

3) permasalahan nelayan dalam proses terbitnya Surat Persetujuan Berlayar (SPB) dan Surat laik Operasi (SLO) oleh Syahbandar dan Pengawas Perikanan;

4) permasalahan nelayan dalam hal penerbitan Surat Keterangan Kecakapan (SKK); dan

5) permasalahan dasar hukum instansi birokrasi dalam hal melakukan kewenangan pelayanan dan penerbitan surat kapal nelayan dan dokumen perizinan usaha nelayan.

Jadi, permasalahan yang terjadi di Karangantu, Pulau Tunda, Sumur dan yang lainnya membutuhkan pengembangan terobosan kreatif bagi semua pihak terutama dari Polair Polda Banten. Beberapa hal yang harus dilakukan Polair Polda Banten dalam pengembangan terobosan kreatif sinkronisasi tersebut adalah pertama Melakukan konsolidasi bersama dengan Dinas Perhubungan Kabupaten/Kotamadya yang melakukan penerbitan pas kecil kapal nelayan yang ukuran 7 (tujuh ) GT ke bawah; kedua melakukan konsolidasi bersama dengan DKP Provinsi, Kabupaten/Kotamadya yang melakukan penerbitan SIUP dan SIPI nelayan; ketiga melakukan konsolidasi bersama dengan Syahbandar Perikanan yang melakukan penerbitan SPB Kapal Nelayan; keempat Melakukan konsolidasi bersama dengan Pengawas Perikanan yang melakukan penerbitan SLO Kapal Nelayan; kelima Melakukan konsolidasi bersama dengan Kantor UPP Ditjend Hubla yang

\footnotetext{
${ }^{9}$ http://id.wikipedia.org/wiki/Polisi_Air_dan_Udara, diakses 12 Juli 2014.
} 
melakukan penerbitan Pas kecil kapal nelayan yang ukuran 7 (tujuh ) GT ke bawah.

Oleh karena itu itu, Polair Polda Banten harus terus turut andil dalam mengambil bagian tugasanya dalam menjaga kerteriban umum, pelayanan masyarakat dan sekaligus penegak hukum di lingkungan operasionalnya. Terebosan kreatif tersebut merupakan niatan untuk membuktikan bahwa Polair mampu untuk mencarikan solusi atas berbagai kebingunan masyarakat nelayan dalam mengurus berbagai dokumen perlengkapan untuk tetap dapat beroperasi. Selama beberapa tahun yang lalu pengurusan dokumen terlalu panjang birokrasinya dan melibatkan banyak pihak. Kehadiran Polair Polda Banten sebagai penengah berbagai benang kusut terkait penanganan persoalan nelayan, baik dari segi kelengkapan dokumen hingga pada kesulitan hidup keseharian nelayan telah dilakukan berbagai pendekatan.

Dalam upaya peningkatan pelayanan tersebut Dit Polair Polda Banten menyelenggarakan terobosan kreatif pelayanan dokmen dengan gratis. Penegakan hukum melalui program penertiban dokumen kapal nelayan dan perizinan usaha perikanan di wilayah hukum Dit Polair Polda Banten, melakukan sinkronisasi dengan instansi pemerintah yang terkait. Tujuan sinkronisasi adalah melakukan pelayanan terhadap nelayan sehingga tidak di temukan adanya penyalahgunaan wewenang dan meningkatkan pelayanan yang cepat. Kemitraan Polair selama ini baik antara nelayan dan instansi terkait dapat terjalin secara bersama-sama menjaga keamanan dan ketertiban masyarakat nelayan dan perairan di wilayah operasional Polair Polda Banten. Hal ini di akui oleh H. Cottang dan Tola ( nelayan Karangantu) yang mengatakan bahwa pelayanan yang di lakukan oleh Pemda, syahbandar dan Polair Polda Banten sangat membantu mempercepat penyelesaian dokumendokumen kapal. Hal senada juga dikemukakan oleh Rahmat warga pulau Tunda.

Untuk menjaga stabilitas keamanan masyarakat pesisir, pulau dan nelayan, Polair Polda Banten beberapa kali menyelenggarakan rapat koordinasi dan konsolidasi. Hal ini dimaksudkan agar terbentuk sinkronisasi upaya terobosan kreatif pelayanan penegakan hukum. Salah satu terobosan kreatif Polair adalah program penertiban dokumen kapal nelayan dan perizinan usaha perikanan di wilayah hukum Polda Banten, yang dilakukan oleh Dit Polair Polda Banten dan Dinas instansi terkait dalam bentuk kegiatan pengukuran ulang kapal nelayan. Polair Polda Banten berhasil melakukan pengukuran ulang sejumlah 1.042 kapal nelayan di bawah 7 GT di 5 wilayah dengan tidak memungut beban biaya kepada nelayan. Kedepannya, Polair Polda Banten bersama pemerintah daerah akan melakukan pengukuran secara gratis terhadap kapal-kapal nelayan yang berukuran di atas 7 GT. 
Dengan langkah terobosan kreatif yang dilakukan oleh Dit Polair Polda Banten sejalan dengan upaya Reformasi Birokrasi Polri dalam program peningkatan kualitas pelayanan publik. Polair di harapkan dapat menciptakan pelayanan prima yang dapat dirasakan oleh masyarakat nelayan. Oleh karena itu, terobosan yang telah dilakukan oleh Dit Polair Polda Banten dapat dituangkan dalam bentuk keputusan bersama Dit Polair Polda Banten dengan unsur-unsur dinas / Instansi terkait Pemda se Provinsi Banten. Dalam rangka peningkatan kualitas pelayanan sesuai dengan Reformasi Birokrasi Polri Dit Polair Polda Banten telah melakukan terobosan kreatif berupa kegiatan sinkronisasi pelayanan terhadap kapal nelayan di wilayah hukum polda Banten hal ini dilakukan berdasarkan analisa dan evaluasi penanganan kasus Illeggal Fishing selama tahun 2010 sampai dengan 2014. Dalam rentang tahun itu, ditemukan masih banyaknya nelayan tidak taat dan patuh terhadap undang-undang dan peraturan pelaksanaan lainnya serta minimnya pengetahuan dan pemahaman birokrasi pemerintah tentang kewenangan dalam pelaksanaan pelayanan terhadap nelayan sebagai akibat dari lemahnya produk hukum daerah yang menyangkut perizinan usaha perikanan yang dikeluarkan oleh dinas terkait.

\section{b. Peningkatan Pendapatan Masyarakat Pesisir}

Karakter masyarakat pesisir merupakan aspek penting dalam sebuah pandangan sosiologi. Setting sosio-edukasi masyarakat pesisir di Indonesia, menjadi penanda karakteristik kultur masyakatnya. Kultur masyarkat pesisir ini akrab dengan ketidakpastian yang tinggi. hal ini disebabkan karena kehidupan sosial di wilayah Pesisir tergantung pada sumber daya laut yang ada. Secara alamiah, sumber daya laut pesisir (perikanan) bersifat invisible, sehingga sulit untuk diprediksi. Dalam kondisi seperti ini maka tidak jarang ditemui karakteristik masyarakat pesisir Indonesia termasuk masyarakat pesisir di Banten yang keras, sebagian tempramental, dan boros karena ada persepsi bahwa sumber daya perikanan "tinggal diambil" di laut. Secara sosiologi perlu adanya transformasi pendidikan dan budaya yang dapat membangun keadaban pesisir-keadaban yang transformatif, tangguh, dan mandiri, bukan keadaban yang lemah, pasif, dan destruktif. ${ }^{10}$

Karakter sosial masyarakat di pesisir ini terbentuk melalui proses panjang. Sebagai contoh adalah fakta sosial masyarakat pesisir di Banten. Karakter sosial pesisiran seperti gaya hidup konsumtif terjadi karena adanya dorongan "gengsi sosial" yang kini semakin tampak menggejala dan merupakan "kompensasi psikologis" dari kesengsaraan hidup yang cukup lama menimpa. Dalam tatanan sosiologis tersebut, kata lain gaya hidup yang

10 http://bukusosiologipesisir.blogspot.com/2013/06/budaya-masyarakat-pesisir.html, 30 November 2014. 
dianggap "boros" itu merupakan upaya masyarakat di pesisir untuk menyenangkan diri sesaat. Gejala sosial yang terjadi di wilayah pesisir Indonesia ini dilakukan dalam menikmati kehidupan yang selayaknya. Streotipe ini sering dianggap menjadi penyebab kemiskian nelayan Pesisir. Padahal kultur soaial masyarakat pesisir, jika dicermati pada dasarnya memiliki etos kerja yang handal. Sebagai contoh, mereka pergi subuh pulang siang, kemudian menyempatkan waktunya pada waktu senggang untuk memperbaiki jaring, dan seterusnya. Kondisi tersebut lambat tapi pasti membentuk dan menjadi identitas mereka.

Masyarakat pesisir Banten, secara sosio kultur-pendidikan lemah dan pasif. Secara struktural mereka termarginalisasi dalam sistem. Marjinalisasi hanyalah satu di antara banyak masalah sosiologis yang timbul sebagai akibat ketimpangan. Di mana ketimpangan ketersediaan sarana sosial ekonomi, pendidikan, kesehatan, dan sarana infrastruktur publik. Marjinalisasi mengabaikan hakikat pemberdayaan masyarakat partisipatif, cenderung mengakibatkan keadaan komunitas pedesaan di pesisir menjadi semakin tidak berdaya dalam beradaptasi terhadap perubahan sosiostruktural dan ekologis. ${ }^{11}$

Oleh karena itu, melihat kondisi masyarakat pesisir Banten di atas, Dit Pol Air Polda Banten yang di komandoi oleh Kombes Imam mengimplementasikan konsep terobosan kreatif terhadap masyarakat/nelayan di wilayah perairan Banten. Terobosan kreatif Polair berupa pengentasan kemiskinan dan pemberdayaan para nelayan untuk bercocok tanam dengan membudidayakan pepaya di Pulau Tunda, Kabupaten Serang, Pemerintah Daerah kabupaten Serang melalui Dinas perkebunan mengatakan bahwa trobosan polair Polda Banten cukup berani dan brilian. Lebih lanjut dikatakan bahwa Polair telah memberikan nilai tambah para nelayan bila saat-saat nelayan tidak bisa melaut, hal ini mungkin bisa di contoh oleh jajaran kepolisian di seluruh tanah air khususnya kepolisian perairan.

Selain di Pulau Tunda, Polair Polda Banten juga memberikan benih kepada masyarakat untuk dikembangkan di pulau Panjang sebanyak 10.000 benih pepaya dari jenis pepaya california dengan nilai pasarnya saat ini khususnya di Jakarta cukup tinggi. Menurut AKBP Taswin (Anggota Polair Polda Banten) kegiatan ini diberi nama Sambang Nusa berupa pembinaan kepada masyarakat perairan di pulau-pulau berpenghuni di wilayah hukum Polda Banten. Untuk terlaksananya kegiatan Sambang Nusa, AKBP Taswin menggandeng UD Prima Agro untuk mengembangkan budidaya pepaya california. Menurut AKBP Taswin kegiatan ini dengan maksud sebagai

${ }^{11}$ Siswanto Sunarso, Wawasan Penegakan Hukum di Indonesia, (Bandung: Citra Aditya Bakti, 2005), hlm. 20. 
wujud peduli nelayan di pulau guna menambah kesejahteraan masyarakat pesisir.

Terobosan kreatif Polair Polda Banten dalam upaya meningkatkan kesejahteraan masyarakat pesisir di akui oleh Rahmat warga pulau Tunda. Rahmat mengatakan bahwa beberapa tahun terakhir warga pulau Tunda memiliki pendapatan tambahan dari budidaya pepaya california dan hawai. Rahmat juga mengatakan bahwa bibit papaya berkwalitas ekspor tersebut di berikan oleh Polair Polda Banten. Jadi, nelayan pulau Tunda di saat angin barat tidak lagi menganggur tapi beralih ke perkebunan papaya mereka dan dapat meningkatkan sumber pendapatan masyarakat pulau Tunda.

\section{c. Penertiban Dokumen Kapal Nelayan}

Dalam upaya peningkatan pelayanan tersebut, Dit Polair Polda Banten menyelenggarakan terobosan kreatif pelayanan penegakan hukum dengan program penertiban dokumen kapal nelayan dan perizinan usaha perikanan di wilayah hukum Polda Banten. Oleh karena itu, kegiatan sinkronisasi dengan instansi pemerintah yang terkait dalam pelayanan terhadap nelayan dapat meminimalisir adanya penyalahgunaan wewenang. ${ }^{12} \mathrm{Hal}$ ini dapat meningkatkan pelayanan kepada nelayan sehingga kedepan kemitraan antara nelayan dan instasi terkait dapat terjalin dan bersama-sama menjaga keamanan dan ketertibatan masyarakat nelayan dapat tercipta.

Secara sosiologis bahwa hubungan sosial dan hubungan struktural fungsional Polair Polda Banten telah melakukan koordinasi yang sangat baik dengan instansi terkait diwilayah kerja Polair Polda Banten. Pola koordinasi yang dilakukan selama ini oleh Polair Banten sudah mengikat sistem kerja yang tidak terpisahkan dengan instansi lainnya. Masyarakat dapat terlayani dengan baik, melalui pola pendekatan yang dilakukan oleh Polair Polda Banten. Berdasarkan pada fakta di lapangan, bahwa selama ini telah berjalan fungsi koordinsi yang diprakarsai oleh Polair Polda Banten. Polair Polda Banten sudah menjalankan tugas dan fungsinya dalam menjaga kerteriban umum, pelayanan masyarakat dan sekaligus penegak hukum di wilayah tugas Polair Polda Banten secara terkoordinasi dan terkonsolidasi dengan instansi yang terkait. Bagi penulis, adanya kerjasama yang intensif dan berkesinambungan antara polair, pemda dan akademisi, maka terobosanterobosan kreatif Polair Polda Banten dapat terwujud dan berkelanjutan. Salah satu program yang dapat dilakukan bersama Polair dan Pemda adalah Pembentukan Samsat Perairan. Samsat perairan ini dapat mempermudah perizinan bagi para kapal-kapal nelayan dan juga dapat meningkatkan

12 Implementasi dari kegiatan sinkronisasi di paparkan pada bagian tentang optimalisasi dukungan Pemda dan Akademisi Terhadap Polair dalam rangka Melindungi, Mengayomi, Melayani Masyarakat, Serta Menegakkan Hukum di Wilayah Perairan Banten. 
Pendapatan Daerah. Ide pembentukan samsat perairan ini di sambut baik oleh Polair dan juga Pemda Banten. Nasir (staf ahli Gubernur Banten) mengatakan bahwa ide pembentukan Samsat Perairan ini merupakan sebuah terobosan untuk memberikan pelayanan terhadap masyarakat nelayan dan di upayakan untuk di realisasikan. Di pihak lain, Polair Polda Banten mengapresiasi ide pembentukan samsat perairan tersebut dengan langkah awal melakukan FGD terkait dengan ide tersebut.

\section{Konsep Pengimplementasian Terobosan Kreatif Polair Polda Banten}

Preemtif, Preventif dan Edukatif merupakan konsep yang di terapkan Polair Polda Banten dalam mendukung kesejahteraan, kepastian dan perlindungan hukum bagi para nelayan di Provinsi Banten. Perlindungan hukum bagi para nelayan di Banten merupakan bagian dari peran penegakan hukum yang sangat di butuhkan untuk menjadi media kontrol dan pencegahan terhadap tindakan-tindakan yang dapat melanggar ketentuan dan peraturan yang berlaku di bidang perikanan dan perundang-undangan lainnya. Adapun program Polair Polda Banten bersama Pemda dan Akademisi dalam hal perlindungan bagi nelayan atau dengan kata lain dalam rangka melindungi, mengayomi, melayani masyarakat, serta menegakkan hukum di wilayah perairan Banten meliputi sebagai berikut:

\section{a. Perlindungan Hukum bagi Nelayan}

Perlindungan bagi nelayan di atur dalam Inpres No. 15 Tahun 2011, Inpres tersebut kemudian di jadikan dasar bagi Polair dalam menerapkan langkah Preemtif, Preventif dan Edukatif.

\section{1) Preemtif}

Upaya preemtif merupakan langkah deteksi terhadap potensi-potensi terjadinya permasalahan-permasalahan hukum pada masyarakat nelayan. Hal ini di lakukan karena ketidaktaatan terhadap hukum, memungkinkan nelayan melakukan pelanggaran dan kejahatan terhadap hukum perikanan atau melakukan tindak pidana perikanan. Oleh karena itu, tindakan preemtif yang di lakukan oleh Polair Polda Banten bersama Pemda Banten meliputi: Pertama, kegiatan pendataan terhadap kapal-kapal nelayan di wilayah Banten mulai kategori ukuran di bawah 7 GT hingga di atas 7 GT; Kedua, Kegiatan pendataan pemilik kapal nelayan yang belum memiliki perizinan usaha perikanan; Ketiga, Kegiatan pendataan kepada nahkoda dan ABK kapal yang belum memiliki surat keterangan kecakapan (SKK); Keempat, kegiatan penelitian yang di lakukan oleh Polair terhadap nelayan dan pemilik di wilayah utara Banten (Kabupaten Serang dan Kota Serang); Kelima, Rapat koordinasi dengan instansi maritim jajaran Provinsi Banten; Keenam, 
Pengukuran fisik kapal nelayan yang di wilayah Karangantu, Bojonegara, Kronjo, Anyar, Labuan Panimbang, Binuangeun; dan Ketujuh, Terbentuknya forum instansi maritim dalam mewadahi pelaksanaan kegiatan dalam memberikan jaminan kesejahteraan, kepastian, dan perlindungan hukum bagi nelayan. Upaya preemtif yang di lakukan oleh Polair ini di rasakan manfaatnya oleh para nelayan dan pemilik kapal seperti yang di rasakan oleh H. Hasyim seorang pemilik kapal di Panimbang. H. Hasyim mengatakan bahwa, selama kegiatan Preemtif di lakukan oleh Polair, para pemilik kapal dan nelayan akhirnya memahami aturan-aturan tentang perizinan dan hal-hal lain yang berkaitan dengan pengurusan administrasi pelayaran.

\section{2) Preventif}

Preventif merupakan usaha-usaha pencegahan terhadap gangguangangguan atau pelanggaran-pelanggaran terhadap norma-norma yang ada di dalam masyarakat. Salah satu pelanggaran hukum yang marak terjadi di perairan Indonesia adalah illegal fishing dan merupakan suatu ancaman yang dapat menganggu stabilitas keamanan negara, khususnya keamanan laut. Mengingat Indonesia sebagai salah satu negara yang memunyai potensial sumber daya perikanan yang cukup besar mengakibatkan permasalahan illegal fishing dan penggunaan alat tangkap. Tekanan penangkapan yang meningkat dari hari ke hari semakin mempercepat penurunan stok sumber daya ikan. Tingginya tekanan penangkapan khususnya di pesisir pantai telah menyebabkan menurunnya stok sumber daya ikan dan meningkatnya kompetisi antar alat penangkapan ikan yang tidak jarang menimbulkan konflik di antara nelayan. Sebagai akibat dari menurunnya pendapatan, nelayan melakukan berbagai macam inovasi dan modifikasi alat penangkapan ikan untuk menutupi biaya operasi penangkapan.

Pelanggaran penggunaan alat tangkap dan metoda penangkapan ikan menjadi trend dalam kegiatan penangkapan ikan. Salah satunya adalah pelanggaran penggunaan trawl (pukat harimau) secara illegal di beberapa wilayah peraiaran termasuk di perairan selat sunda yang merupakan wilayah hukum Polda Banten. Oleh karena itu, upaya yang harus dilakukan oleh Polair dalam rangka pencegahan penggunaan alat tangkap yang dilarang adalah melaksanakan kegiatan Patroli dalam rangka memberikan perlindungan dan pelayanan dengan mendatangi tempat nelayan untuk pemolisian masyarakat (Polmas). Selain itu, Polair Polda Banten dapat menugaskan anggota gakkum bersama jajaran instansi maritim lainnya menyosialisasikan program pengukuran kapal dan meminta kepada nelayan agar mempersiapkan persyaratan dalam pelaksanaan pengukuran ulang hingga proses penerbitan dokumen yang baru terhadap kapal dan nahkoda kapal serta proses penerbitan perizinan usaha perikanan. 
Upaya preventif lainnya yang dapat di lakukan secara rutin atau berkesinambungan adalah sambangnusa kepada masyarakat perairan yang ada di pulau-pulau terdekat, guna penyampaian tentang kegiatan yang akan di laksanakan terkait sinkronisasi pelayanan, pendaftaran dan kebangsaan kapal serta perizinan usaha perikanan. Namun yang tak kala pentingnya yang mendesak untuk di lakukan oleh Polair bersama dengan dinas maritim terkait adalah pemetaan terhadap daerah-daerah rawan kriminalitas dalam bentuk Analisa Daerah Operasi (ADO), optimalisasi intelejen dan serse dalam rangka memberikan rasa aman terhadap nelayan dalam beraktivitas dengan jalan memperbanyak kegiatan patrol antisipasi terhadap kejahatan kriminal terhadap nelayan.

\section{3) Edukatif}

Edukatif atau mendidik adalah upaya yang dapat dilakukan oleh Polair Polda Banten dalam upaya tertib hukum bagi para nelayan dan pemilik kapal di perairan Banten. Oleh karena itu, upaya Polair dalam rangka edukatif tersebut adalah dengan di lakukannya sosialisasi hukum kepada Nahkoda dan pemilik kapal dalam rangka memahami perundang-undangan dan peraturan terkait dengan pendaftaran dan kebangsaan kapal, perizinan usaha perikanan, ketentuan pidana bidang perairan sehingga di harapkan para nelayan dan pemilik kapal paham dan patuh terhadap perundang-undangan yang berlaku. Pelaksanaan kegiatan sosialisasi di laksanakan di 3 (tiga) tempat yakni di ruang pertemuan nelayan di pelabuhan nusantara Karangantu diikuti sebanyak 350 nahkoda kapal dan 300 pemilik, di ruang pertemuan nelayan Binuangeun Kabupaten Lebak sebanyak 250 nahkoda kapal dan 300 pemilik serta pertemuan nelayan di Labuan Kabupaten Pandeglang sebanyak 350 nahkoda kapal dan 300 pemilik.

Selain itu, tindakan lain yang dilakukan Polair dalam wujud edukatif adalah memberikan buku panduan nelayan yang berisi tata cara pengurusan dan pelayanan terhadap dokumen kapal nelayan baik ukuran di bawah 7 GT maupun di atas $7 \mathrm{GT}$, tata cara pengurusan dan pelayanan perizinan usaha perikanan serta tata cara penerbitan dan pelayanan surat keterangan kecakapan bagi nahkoda dan ABK kapal nelayan. Pemberian buku tersebut di atas kemudian ditindaklanjuti dengan pelatihan kecakapan bagi para nelayan yang di lakukan di beberapa tempat diantaranya di Karangantu Kota Serang, Binuangen Kabupaten Lebak dan Labuan Kabupaten Pandeglang.

\section{Penutup}

\section{Simpulan}

Pola Pengembangan Terobosan Kreatif yang di lakukan Kepolisian Perairan Banten dalam Rangka Mendorong Eksistensi Kepolisian Perairan di 
Banten adalah melakukan singkonisasi dan koordinasi dengan Dinas Maritim Provinsi Banten dalam hal pengukuran Kapal, Perumusan Peraturan Daerah terkait dengan pelayanan terhadap nelayan dan rencana pembuatan samsat perairan;

Optimalisasi dukungan Pemda, Akademisi Guna Mengatasi Situasi, Kebutuhan dan pengimplementasian terobosan kreatif Polair Banten dalam rangka Melindungi, Mengayomi, Melayani Masyarakat, Serta Penegakkan Hukum di Wilayah Perairan dapat di wujudkan melalui tindakan Preemtif, Preventif dan Edukatif serta kerjasama yang berkelanjutan dengan membentuk forum maritim sebagai wadah berkumpulnya instansi-instansi yang membidangi wilayah perairan maritim serta pelabuhan-pelabuhan di Provinsi Banten.

\section{Saran}

a. agar Pemerintah Pusat menambah anggaran kepolisian khususnya anggaran Patroli bagi Kepolisian Perairan;

b. agar Pemerintah Daerah mempersiapkan dukungan Fasilitas, konsep dan anggaran serta ahli dalam pelayanan terhadap nelayan dan penegakan hukum; dan

c. agar Pemerintah Daerah dapat bersinergi dengan Kepolisian Perairan Polda Banten dalam dalam mewujudkan samsat Perairan.

\section{Daftar Pustaka}

\section{A. Buku}

Mansur, Dikdik M. Arief, 2011, Bunga Rampai Implementasi Tugas Pokok POLRI, Bandung: LoGoz Publisihing.

Mochtar, Kusumaatmadja, 1978, Hukum Laut Internasional, Bandung: Bina Cipta.

Moleong, Lexy J., 1998, Metode Penelitian Kualitatif, Bandung: PT. Remaja Rosda Karya.

Sadjijono, M. Khoidin, 2005, Menatap Wajah Polisi Kita, Yogyakarta: Laksbang PRESSindo.

Nasution, 2003, Metode Penelitian Naturalistik Kualitatif, Bandung: Tarsito. Anonimus, 1983, Konvensi PBB tentang Hukum Laut, Direktorat Perjanjian Internasional, Departemen Luar Negeri.

Roberg, Roy R, 2013, Police Management, Terjemahan oleh PTIK, Jakarta. Taswin, Kumpulan hasil laporan Polair Polda Banten sejak tahun 2000-2014. Rahardjo, Satjipto, 2009, Penegakan Hukum Suatu Tinjauan Sosiologis, Yogyakarta: Genta Publishing.

Soekanto, Soerjono, 1996, Pengantar Penelitian Hukum, Jakarta: UI Press. 
Sirajuddin, dkk, 2007, Komisi Pengawas Penegak Hukum, Malang: Malang Corruption Watch daan Yappika.

Sunarso, Siswanto, 2005, Wawasan Penegakan Hukum di Indonesia, Bandung: Citra Aditya Bakti.

\section{B. Peraturan perundang-undangan}

Undang-undang Nomor 4 Tahun 1960 tentang Perairan Indonesia.

Undang-undang Nomor 17 Tahun 1985 tentang Pengesahan United Nation

Convention of the Law of the Sea 1982.

Undang-undang Nomor 6 Tahun 1996 tentang Perairan.

Peraturan Pemerintah Nomor 8 Tahun 1962 tentang Hak Lintas Damai kendaraan Air Asing.

Peraturan Pemerintah Nomor 36 Tahun 2002 tentang Hak dan Kewajiban Kapal Asing dalam Melaksanakan Lintas Damai Melalui Perairan Indonesia.

Peraturan Pemerintah Nomor 19 Tahun 1999 tentang Pengendalian dan Perusakan Laut.

\section{Internet}

http://id.wikipedia.org/wiki/Polisi_Air_dan_Udara, diakses 12 Juli 2014 http://www.pelita.or.id/baca.php?id=97609 di akses tanggal 12 Juli 2014 http://www.polair.polri.go.id/index.php?option=com_content\&view=article

\&id=1061\&Itemid=597 di akses tanggal 1 Oktober 2014

http://melodiramadhinion.blogspot.com/2011/11/pelanggaran-dan-kejahatandi-wilayah.htm, di akses tanggal 1 September 2014 http://female.kompas.com, 23 November 2009 http://bukusosiologipesisir.blogspot.com/2013/06/budaya-masyarakatpesisir.html, 30 November 2014 